\title{
Alkaline Solubilization of Chicken Tissues Monitored by Raman Spectroscopy Followed by Pb Determination by GF AAS
}

\author{
Náira S. Campos, ${ }^{a}$ Marcone A. L. de Oliveira, ${ }^{a}$ Celly M. S. Izumi ${ }^{b}$ and \\ Rafael A. de Sousa ${ }^{*, a}$ \\ ${ }^{a}$ Grupo de Química Analítica e Quimiometria (GQAQ) and \\ ${ }^{b}$ Laboratório de Nanoestruturas Plasmônicas (LabNano), \\ Universidade Federal de Juiz de Fora, 36036-900 Juiz de Fora-MG, Brazil
}

\begin{abstract}
This paper proposes a method for chicken tissues preparation using tetramethylammonium hydroxide (TMAH) for $\mathrm{Pb}$ determination by graphite furnace atomic absorption spectrometry employing multivariate approaches. Combining Raman spectroscopy with scanning electron microscopy coupled to energy-dispersive X-ray spectroscopy to monitor the solubilization process it was possible to show that TMAH acts in the solubilization of proteins, amino acids and lipids. Besides, this investigation showed that the small residual masses of samples have organic and inorganic compounds. Accuracy tests indicated that such residues have not interfered in the analytical results (recovery between $90-95 \%)$. The obtained limits of detection $\left(0.099 \mu \mathrm{g} \mathrm{g}^{-1}\right)$ and quantification $\left(0.33 \mu \mathrm{g} \mathrm{g}^{-1}\right)$ are compatible with the detectability required for regulatory purposes. Linearity $\left(\mathrm{R}^{2}=0.9925\right)$ and characteristic mass $(13 \mathrm{pg})$ were also reported. Considering the set of 15 samples comercialized in Brazil, any $\mathrm{Pb}$ contamination was successfully observed and this was confirmed by the analysis of digested samples.
\end{abstract}

Keywords: atomic absorption spectrometry, chicken, Pb, TMAH, Raman spectroscopy

\section{Introduction}

World Health Organization ${ }^{1}$ recognizes lead $(\mathrm{Pb})$ as one of the most dangerous metallic species for health. This element has no essential functions for living beings, especially mammals, and tends to accumulate in bones causing a series of irreversible biochemical changes. The main health disorders caused by $\mathrm{Pb}$ poisoning are cognitive problems in children, decreased fertility in men, and reduced kidney functions. ${ }^{1,2}$

According to the literature, $\mathrm{Pb}$ poisoning occurs primarily due to environmental contamination and ingestion of contaminated food and water. In Brazil, the Brazilian Health Regulatory Agency (ANVISA) provides the maximum tolerance for $\mathrm{Pb}$ in some foods. For chicken meat and viscera, the limits are 100 and $500 \mu \mathrm{g} \mathrm{kg}^{-1}$, respectively. ${ }^{3}$ These values are in agreement with those regulated by both European Community ${ }^{4}$ and Mercosur. ${ }^{5}$

For the spectrometric determination of trace elements such as $\mathrm{Pb}$ in solid samples, it is usually necessary to perform a matrix dissolution step prior to analysis. This

*e-mail: rafael.arromba@ufjf.edu.br is conventionally achieved by dry ash or acid digestions (using hot plates or microwave systems) leading to total sample decomposition. Although such conventional digestion procedures have been widely used in routines, these procedures can be long and the samples manipulation favors analyte loss and/or sample contamination. ${ }^{6}$ In this sense, there is a search for sample preparation procedures involving minimum sample handling, avoiding analyte loss and sample contamination.

Alternative methods for acid digestions were carried out using different extraction and solubilization procedures, which can be applied as adequate sample preparation especially for trace and speciation analysis. Different species of arsenic (inorganic, methylarsonic acid, dimethylarsinic acid and arsenobetaine) were determined in fish-based baby food using suspensions prepared in tetramethylammonium hydroxide (TMAH) solution and determinations by electrothermal atomic absorption spectrometry (ET AAS) by standard additions method. The obtained limits of detection (LOD) were quite satisfactory and the method showed to be appropriate for rapid determinations, avoiding extraction processes and/or chromatographic separations. ${ }^{7}$ In another work, an ultrasound assisted extraction, using 
solutions of TMAH, was utilized for the speciation analysis of mercury (inorganic and methyl mercury) in fish and plant tissues, with detection by cold vapor atomic absorption spectrometry (CV AAS). The method was validated by using a certified reference material and showed good detectability. ${ }^{8}$ In this context, the alkaline reagent TMAH was used in this work due to its property to dissolve protein samples, which are usually poorly soluble in water. ${ }^{9}$

Several studies using TMAH have been reported to prepare biological samples such as hair, ${ }^{10}$ nails ${ }^{11}$ and animal tissues. ${ }^{12-18}$ In general, the results have shown a reduction in the sample preparation time, good stability for the obtained sample solution/suspension and a full or partial dissolution of the sample in aqueous medium. ${ }^{9}$ However, the ideal conditions for TMAH use, like extraction time and solution volume, as well the chemical mechanisms of the reagent action are poorly understood.

In order to study the sample solubilization with TMAH, Raman spectroscopy has been used. This spectroscopic technique is based on the inelastic scattering of electromagnetic radiation that interacts differently with different molecules. Specifically for Fourier transform (FT)-Raman spectroscopy, monochromatic near-infrared light is scattered with a different frequency from the incident radiation and samples spectrum can be obtained and compared. Importantly, the frequency variation corresponds to the energy difference between two vibrational states of the molecule, and may be assigned to functional groups. ${ }^{19}$

In addition, Raman spectroscopy is a versatile and rapid technique, which makes possible the simultaneous determination of more than one component, without the need for samples pre-treatment step so that there is no generation of toxic waste products. Therefore, it offers analytical opportunities for many areas of production, quality inspection and control, including food industry. ${ }^{19-22}$ Lopez-Diez et al. ${ }^{21}$ proposed a method to evaluate the potential of Raman spectroscopy allied to chemometrics to detect adulterations in olive oil by very closely related oils.

The levels of hazelnut oils used to adulterate extra virgin olive oil were successfully quantified using partial least squares and genetic programming. Goodacre et al. ${ }^{22}$ also used this combination for differentiating honey samples according to their geographical and botanical origin.

The chemometric clustering method indicated that the major differences between the honeys were due to their botanical origin rather than the culture region. Another interesting study ${ }^{19}$ that also employed chemometric methods combined to FT-Raman spectroscopy verified the adulteration of milk powder samples, commercialized in Brazil, by starch additions.
Aiming to generate useful information on food contamination, this work describes an analytical method for the determination of $\mathrm{Pb}$ in different tissues of visceral parts of chicken, which is one of the main protein sources for human nutrition. For this purpose, the graphite furnace atomic absorption spectrometry (GF AAS) was selected as an adequate analytical technique due to high sensitivity and compatibility with complex samples such as solubilized extracts. For the samples solubilization, TMAH was used and the Raman spectroscopy was employed as a tool to monitor the solubilization of the samples studied.

\section{Experimental}

\section{Apparatus and reagents}

All materials were washed in neutral soap, soaked in $10 \%(\mathrm{v} / \mathrm{v})$ nitric acid for $24 \mathrm{~h}$ and then washed with deionized water prior to use. Deionized water was obtained with a Milli-Q System (Millipore, Bedford, MA, USA).

A $1000 \mu \mathrm{g} \mathrm{m}^{-1} \mathrm{~Pb}$ solution (Qhemis High Purity, Jundiaí, SP, Brazil) was used to prepare standard solutions with concentrations between 5.0 and $40 \mu \mathrm{g} \mathrm{L}^{-1}$. The chemical modifier was prepared from $10 \mathrm{~g} \mathrm{~L}^{-1} \mathrm{NH}_{4} \mathrm{H}_{2} \mathrm{PO}_{4}$ solution (PerkinElmer, São Paulo, SP, Brazil).

For alkaline sample solubilization, $25 \%(\mathrm{v} / \mathrm{v})$ tetramethylammonium hydroxide (TMAH, Sigma-Aldrich, St. Louis, MO, USA) was used. A microwave oven from Berghof (model Speed Wave Four) was used for the acid sample digestion employing nitric acid (reference method).

A Thermo Scientific atomic absorption spectrometer, model SOLAAR M5 (Waltham, MA, USA) equipped with deuterium background corrector, conventional graphite furnace with longitudinal heating (HGA) was used for all $\mathrm{Pb}$ determinations. $\mathrm{A} \mathrm{Pb}$ hollow cathode lamp was used as radiation source $(217.0 \mathrm{~nm})$ with bandpass of $0.5 \mathrm{~nm}$. The measurements were made by integrated absorbance units. The inert gas employed was pure argon at flow rate of $200 \mathrm{~mL} \mathrm{~min}^{-1}$ (except during atomization step).

The FT-Raman spectra were collected on an FT-Raman spectrometer, model RFS-100/S from Bruker Optics, using $1064 \mathrm{~nm}$ wavelength for excitation (Nd:YAG laser Coherent Compass 1064-500N) and a Ge detector. Scanning electron microscopy (SEM) images of solubilization residues have been done at a tabletop Hitachi TM 3000 instrument featuring improved electron optics, higher magnification, and built-in image processing to further enhance image quality and resolution at lower accelerating voltage; working in 5 or $15 \mathrm{kV}$, and magnification from $15 \times$ to 30,000x. Energy dispersive X-ray spectrophotometer Quantax 70 EDX from Bruker has also been used with 
light element detection from boron upwards, with available linescan, mapping and multiple point analysis at the sample.

Samples acquirement and instrumental conditions

Edible samples of tissues of visceral parts of chicken were purchased from a local market. The visceral samples were heart, liver and gizzard tissues. An amount of 5 different samples (ca. $250 \mathrm{~g}$ each) of each tissue were collected and analyzed.

The samples were grounded in a domestic knife mill and dried in a vacuum oven at $70 \pm 1{ }^{\circ} \mathrm{C}$ for $72 \mathrm{~h}$. Then, the samples were milled again, placed in plastic flasks and stored in room temperature $\left(25^{\circ} \mathrm{C}\right)$. Prior to analysis, a test sample was prepared for each kind of tissue. For this purpose, approximately $1 \mathrm{~g}$ of five different samples of the same kind was mixed and then appropriate amounts of this mixture was used to all optimization steps.

For the GF AAS instrumental conditions optimization, pyrolysis and atomization curves were obtained using a $25 \mu \mathrm{g} \mathrm{\textrm {L } ^ { - 1 }} \mathrm{Pb}$ standard solution, prepared in $0.2 \%(\mathrm{v} / \mathrm{v})$ $\mathrm{HNO}_{3}$ or $1.75 \%(\mathrm{v} / \mathrm{v})$ TMAH, and containing $1 \%(\mathrm{v} / \mathrm{v})$ $\mathrm{NH}_{4} \mathrm{H}_{2} \mathrm{PO}_{4}$ as chemical modifier. A blank solution for each media (TMAH or $\mathrm{HNO}_{3}$ ) was properly employed. Besides that, the analytical performance for both conventional and pyrolytic graphite tubes in both media (acid and alkaline) was evaluated by comparing some figures of merit.

The Raman spectra of samples were collected before and after alkaline sample preparation. Before alkaline solubilization, Raman spectra were recorded with laser power of $100 \mathrm{~mW}$ focused on the dried and milled test samples (one test sample for each sample kind). For each spectrum, an average of 1024 scans (ca. $25 \mathrm{~min}$ ) was collected with a resolution of $4 \mathrm{~cm}^{-1}$ over the range between 3500 and $500 \mathrm{~cm}^{-1}$. After alkaline solubilization, a small amount of suspended material was observed and the extracts of each test sample were filtered through a teflon (PTFE) Millipore membrane $(0.22 \mu \mathrm{m})$. Then, the residue of filtration was collected and Raman spectra were obtained with laser power of $10 \mathrm{~mW}$ focused on the residues. In this case, an average of 1024 scans was collected using the same experimental conditions.

In association to Raman spectroscopy, the scanning electron microscopy with energy-dispersive X-ray spectroscopy (SEM-EDS) technique was used to evaluate such residues composition, providing information about inorganic species.

GRAMS AI32 and Origin Pro 8 software were used for baseline correction, sum and normalization for the most intense band of each spectrum. These parameters were selected in order to obtain the best signal-to-noise ratio while the physical and chemical integrity of the samples was maintained. The software OPUS 6.0 (Bruker Optik, Ettlingen, Germany) was used for Raman data acquisition.

\section{Figures of merit}

In the absence of a certified reference material for visceral parts of chicken tissues, we resorted to addition and recovery experiments to estimate the accuracy of the developed method according to International Union of Pure and Applied Chemistry (IUPAC) recommendations. ${ }^{23}$ The spiking levels were selected at two concentrations, 5.0 and $30 \mu \mathrm{g} \mathrm{L}^{-1}$, low and high levels selected based on the calibration range. Besides, all the $\mathrm{Pb}$ additions were made before the sample preparation.

The results were also compared with the ones obtained when a complete digestion was carried out, which was referred to as reference method. Precision was assessed by monitoring the relative standard deviation (RSD). The limits of detection (LOD) and quantification (LOQ) were also calculated as the IUPAC ${ }^{24}$ recommendations. For the external calibration curve: $\mathrm{LOD}=3 \mathrm{sB} / \mathrm{S}$ and $\mathrm{LOQ}=10 \mathrm{sB} / \mathrm{S}$, where $\mathrm{sB}$ is the standard deviation of 10 consecutive measurements of the digestion blank and $\mathrm{S}$ is the slope of the respective analytical curve. Besides, the linear working range and linearity were also determined using parametric statistical tools.

On the other hand, in order to provide a measure for the sensitivity of the analyte under selected conditions, the characteristic mass $\left(\mathrm{m}_{0}\right)$ approach was performed. This parameter is the mass of analyte necessary to generate $1 \%$ of absorption (absorbance signal $=0.0044$ ). This mass was calculated for both media using equation 1 , where $V_{S}$ is the sample volume introduced into the graphite furnace $(30 \mu \mathrm{L})$ and $\mathrm{b}$ corresponds to the slope of the used analytical curve. ${ }^{25}$

$\mathrm{m}_{0}=\frac{\mathrm{V}_{\mathrm{s}} \times 0.0044}{\mathrm{~b}}$

\section{Sample treatment}

\section{Acid digestion (reference method)}

Usually, the complete digestion is performed using concentrated or diluted nitric acid $\left(\mathrm{HNO}_{3}\right)$ and/or hydrogen peroxide. ${ }^{26-32}$ In the present work, the complete digestion of chicken tissue samples was employed as a reference method. Briefly, ca. $0.25 \mathrm{~g}$ of dried chicken tissues was mixed with $5.00 \mathrm{~mL}$ of $7.00 \mathrm{~mol} \mathrm{~L}^{-1} \mathrm{HNO}_{3}$ directly in PTFE vessels, and left for $30 \mathrm{~min}$ in predigestion. A blank solution was prepared using the same reagents and experimental conditions applied to the samples. After that, the vessels 
Table 1. Microwave digestion program used to prepare chicken meat samples

\begin{tabular}{lcccc}
\hline Step & Temperature $/{ }^{\circ} \mathrm{C}$ & Heating time $/$ min & Hold time $/$ min & Power $/ \mathrm{W}$ \\
\hline 1 & 200 & 15 & 30 & 1200 \\
2 & 50 & 1 & 10 & 0 \\
\hline
\end{tabular}

Table 2. Heating program used to determine $\mathrm{Pb}$ in chicken meat after acid or alkaline sample preparation

\begin{tabular}{lcccc}
\hline Step & Temperature $/{ }^{\circ} \mathrm{C}$ & Ramp $/\left({ }^{\circ} \mathrm{C} \mathrm{s}^{-1}\right)$ & Hold $/ \mathrm{s}$ & Ar flow rate $/\left(\mathrm{mL} \mathrm{min}^{-1}\right)$ \\
\hline Drying & 100 & 10 & 30 & 200 \\
Pyrolysis & $800^{\mathrm{a}} / 1000^{\mathrm{b}}$ & 150 & 20 & 200 \\
Atomization & $1500^{\mathrm{b}} / 2000^{\mathrm{a}}$ & 0 & 3 & 0 \\
Clean up & 2500 & 0 & 3 & 200 \\
\hline
\end{tabular}

${ }^{\mathrm{a}}$ Alkaline medium; 'bacid medium; chemical modifier: $1 \%(\mathrm{v} / \mathrm{v}) \mathrm{NH}_{4} \mathrm{H}_{2} \mathrm{PO}_{4}$.

were closed and the samples were digested in microwave oven under the conditions shown in Table 1.

Clear solutions were obtained and seemed to be appropriate for subsequent analyzes. Next, the samples were transferred quantitatively to graduate weighed polypropylene tubes, diluted to $25 \mathrm{~mL}$ with deionized water, weighed again and then analyzed following the conditions shown in Table 2.

\section{Alkaline solubilization}

In preliminary tests, the $\mathrm{Pb}$ signal obtained was lower than instrumental limit of detection. To overcome that limitation, we resorted to a dry sample of a male rat liver of Wistar Hanover, which already contained $\mathrm{Pb}$. This sample was utilized as a model to optimize the sample preparation because it was from an animal whose tissues already contained the analyte of interest. This sample was previously generated in a previous study, regarding $\mathrm{Pb}$ toxicology in rats. ${ }^{16}$

To optimize the alkaline sample preparation, the variables solubilization time (hours), $\mathrm{X}_{1}$ and TMAH volume $(\mathrm{mL}), \mathrm{X}_{2}$, were evaluated by means of a $2^{2}$ composite central design (CCD), that is, a two-level factorial design including 4 experiments in axial conditions and 3 repetitions in central point. ${ }^{33,34}$ Thus, the sample mass was fixed at $0.25 \mathrm{~g}$ and a total of 11 random experiments were performed and the response data were processed using the software Microsoft Excel 2010. The codified matrix containing factors, experimental levels and the response data obtained by $\mathrm{Pb}$ concentration $\left(\mu \mathrm{g} \mathrm{g}^{-1}\right)$, by each experiment, are given in Table 3. Using a fitted full quadratic model (equation 2), a response surface regression analysis using coded units was performed for each response factor.

$\hat{y}=\hat{\beta}_{0}+\sum_{i=1}^{k} \hat{\beta}_{i} x_{i}+\sum_{i=1}^{k} \hat{\beta}_{i i} x_{i}^{2}+\sum_{i} \sum_{j} \hat{\beta}_{i j} x_{i} x_{j}+r_{i} \quad i<j$
Table 3. Coded $2^{2} \mathrm{CCD}$ containing levels, factors and response of $\mathrm{Pb}$

\begin{tabular}{lccc}
\hline Issue & $\mathrm{X}_{1}$ & $\mathrm{X}_{2}$ & $\mathrm{~Pb} /\left(\mu \mathrm{g} \mathrm{g}^{-1}\right)$ \\
\hline 1 & -1 & -1 & 39.4 \\
2 & 1 & -1 & 29.2 \\
3 & -1 & 1 & 30.3 \\
4 & 1 & 1 & 39.3 \\
5 & 0 & 0 & 51.3 \\
6 & 0 & 0 & 66.2 \\
7 & 0 & 0 & 50.4 \\
8 & -2 & 0 & 31.6 \\
9 & 0 & 2 & 27.2 \\
10 & 2 & 0 & 49.2 \\
11 & 0 & -2 & 32.9 \\
\hline
\end{tabular}

$\mathrm{X}_{1}$ : TMAH volume, $\mathrm{mL}:(-2): 0.75 ;(-1): 1.25 ;(0): 1.75 ;(1): 2.25 ;(2)$ : 2.75; $\mathrm{X}_{2}$ : time, h: (-2): 4; (-1): 6; (0): 8; (1): 10; (2): 12.

It should be mentioned that after alkaline solubilization, the sample solutions presented a brownish-yellow color and a little amount of foam (observed after shaking), which disappeared completely after a few minutes ( $3 \mathrm{~min}$ in general). The solubilized samples were transferred quantitatively to graduated polypropylene tubes (previously weighed), diluted to $25 \mathrm{~mL}$ with deionized water, weighed again and then stored under ambient temperature until the analysis. A blank solution was prepared using the same experimental conditions applied to the samples. The $\mathrm{Pb}$ content in the samples was quantified approximately $12 \mathrm{~h}$ after preparation, using the conditions shown in Table 2.

\section{Results and Discussion}

\section{GF AAS optimization}

The pyrolysis and atomization curves obtained for the $\mathrm{Pb}$ determination are shown in Figures 1 and 2, respectively, 
in both acid (reference) and alkaline (proposed) media. The optimal conditions were selected by comparing the integrated absorbance and the heating program employed for the GF AAS analysis are shown in Table 2. For acid medium, $1000^{\circ} \mathrm{C}$ was selected for the pyrolysis, since this temperature presented the highest integrated absorbance. Consequently, the atomization curve was obtained after fixing the pyrolysis temperature at $1000{ }^{\circ} \mathrm{C}$. In this case, the optimum atomization temperature was determined as $1500{ }^{\circ} \mathrm{C}$. For alkaline medium the same procedure was adopted and the selected pyrolysis and atomization temperatures were 800 and $2000{ }^{\circ} \mathrm{C}$, respectively.

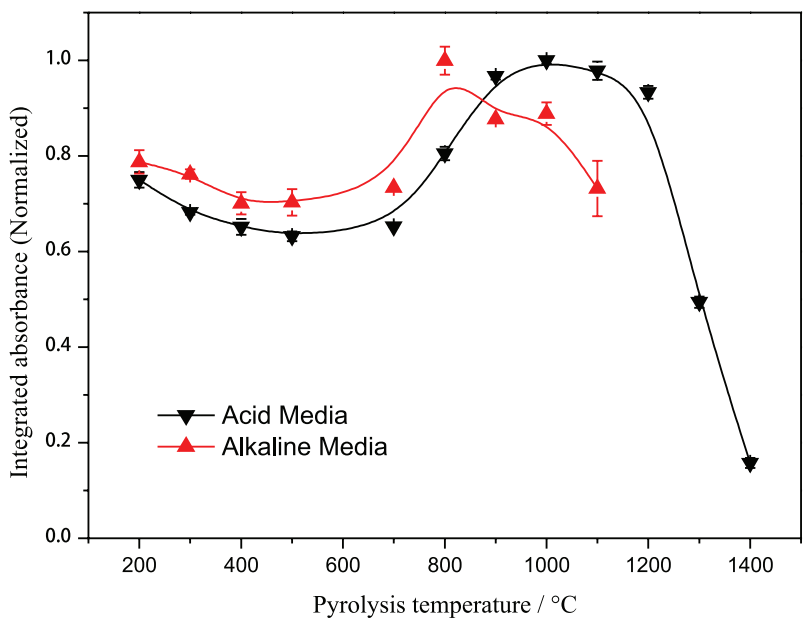

Figure 1. Pyrolysis curves for $25 \mu \mathrm{g} \mathrm{L} \mathrm{L}^{-1} \mathrm{~Pb}$ standard solution in acid $\boldsymbol{\nabla}$ $\left(0.2 \% \mathrm{v} / \mathrm{v} \mathrm{HNO}_{3}\right)$ and alkaline media $\boldsymbol{\Delta}(1.75 \% \mathrm{v} / \mathrm{v} \mathrm{TMAH})$. Temperature used for atomization: $1200{ }^{\circ} \mathrm{C}$.

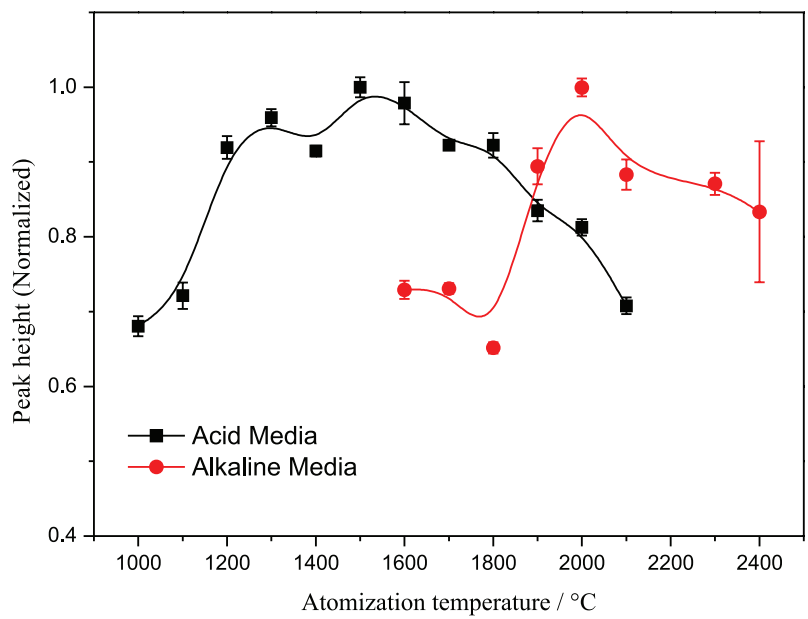

Figure 2. Atomization curves for $25 \mu \mathrm{g} \mathrm{L}{ }^{-1}$ lead standard solution in acid $\left(0.2 \% \mathrm{v} / \mathrm{v} \mathrm{HNO}_{3}\right)$ and alkaline media $(1.75 \% \mathrm{v} / \mathrm{v} \mathrm{TMAH})$. Temperature used for pyrolysis: acid media, $1000{ }^{\circ} \mathrm{C}$; and alkaline media, $800{ }^{\circ} \mathrm{C}$.

\section{Alkaline solubilization}

Alternative methods for sample preparation that involve the minimum sample handling as well as reduction in time and/or reagents consumption, which result in reduction of analyte loss or sample contamination are being preferred. ${ }^{9,16}$ In this work, the alkaline solubilization attends the above advantages and so the extraction conditions were studied.

As mentioned previously, a dry liver sample of a male rat was employed as a sample model for the alkaline solubilization studies. ${ }^{16}$ This sample was chosen for containing the analyte of interest and to be a tissue relatively similar to the actual samples.

Table 4 shows the calculated values for coefficients and $p$-values ( $p$-value is the probability of the null hypothesis). Using $\alpha=0.05$, a factor is considered to affect the response if the coefficients differ significantly from zero and $p$-value $<0.05$. In the present case, calculated $p$-values indicated that the investigated variables presented no statistically significant effect on the response ( $p$-value $>$ 0.05 ) within the investigated level range. ${ }^{33}$ Moreover, the fit model was evaluated (analysis of variance (ANOVA) test) and the result found indicated that no evidence of lack of fitting was observed within $95 \%$ confidence interval ( $p$-value $=0.09$, higher than 0.05).

Considering the response obtained in Table 3, it would be important to highlight that the results observed by $2^{2} \mathrm{CCD}$ design indicated no obvious behavior. For instance, when the TMAH volume level was maintained fixed in level -1 , which means $1.25 \mathrm{~mL}$ of TMAH solution, and the time was changed in the range from 6 to $10 \mathrm{~h}$ (taking into account issues 1 to 3 ), the amount of $\mathrm{Pb}$ in average decreased from 39.4 to $30.3 \mu \mathrm{g} \mathrm{g}^{-1}$. Similar behavior was also observed when the TMAH volume was maintained fixed in level 0 (1.75 mL TMAH solution), and the time changed in the range from 4 to $12 \mathrm{~h}$ (taking into account issues 11 to 9), the amount of $\mathrm{Pb}$ in average increased from 27.2 to $32.9 \mu \mathrm{g} \mathrm{g}^{-1}$. On the other hand, in univariate approaches, usually the amount of extracted $\mathrm{Pb}$ only increases if the extraction time increases. On the other hand, when the TMAH level is maintained fixed in level +1 ( $2.25 \mathrm{~mL}$ of TMAH solution), and the time change in the range from 6 to $10 \mathrm{~h}$ (taking into account issues 2 to 4 ) the amount of $\mathrm{Pb}$ in average increases from 29.2 to $39.3 \mu \mathrm{g} \mathrm{g}^{-1}$, which is in accord to the expected behavior. The increases of response of $\mathrm{Pb}$ amount from 31.6 to $49.2 \mu \mathrm{g} \mathrm{g}^{-1}$ has been verified for TMAH volume changes from level -2 $(0.75 \mathrm{~mL})$ to $+2(2.75 \mathrm{~mL})$ and extraction time was fixed in level $0(8 \mathrm{~h})$. Finally, it should be noticed that the amount of extracted $\mathrm{Pb}$ did not increase only by increasing the extraction time, so that it was observed a dependence on parameters combination.

It was verified no evidence of lack of fit in $95 \%$ interval, and the response surface plotted in Figure 3 
Table 4. Values obtained for coefficients, standard error, $t$-test and $p$-values with a $2^{2}$ CCD design for alkaline sample solubilization

\begin{tabular}{lcccc}
\hline Coefficient & $\begin{array}{c}\text { Regression } \\
\text { coefficient }\end{array}$ & $\begin{array}{c}\text { Standard } \\
\text { error }\end{array}$ & $\mathrm{t}(2)$ & $p$-Value \\
\hline $\mathrm{b}_{0}$ & 51.3 & 4.5 & 11.3 & 0.01 \\
$\mathrm{~b}_{1}$ & 2.83 & 2.55 & 1.11 & 0.38 \\
$\mathrm{~b}_{2}$ & -0.87 & 2.55 & -0.34 & 0.76 \\
$\mathrm{~b}_{11}$ & -3.60 & 2.01 & -1.79 & 0.22 \\
$\mathrm{~b}_{22}$ & -6.19 & 2.01 & -3.08 & 0.09 \\
$\mathrm{~b}_{12}$ & 4.81 & 4.42 & 1.08 & 0.39 \\
\hline
\end{tabular}

indicates that the maximum $\mathrm{Pb}$ content in liver rats was extracted using $1.75 \mathrm{~mL}$ of TMAH $(25 \% \mathrm{~m} / \mathrm{v})$ and $8 \mathrm{~h}$ of solubilization (maximum point). Considering that the main constituents of both rat and chicken tissues are animal proteins, this optimal condition was applied to extract the $\mathrm{Pb}$ content in chicken tissues. For this purpose, the optimized instrumental parameters were utilized and the composite samples were first analyzed in order to evaluate some figures of merit.

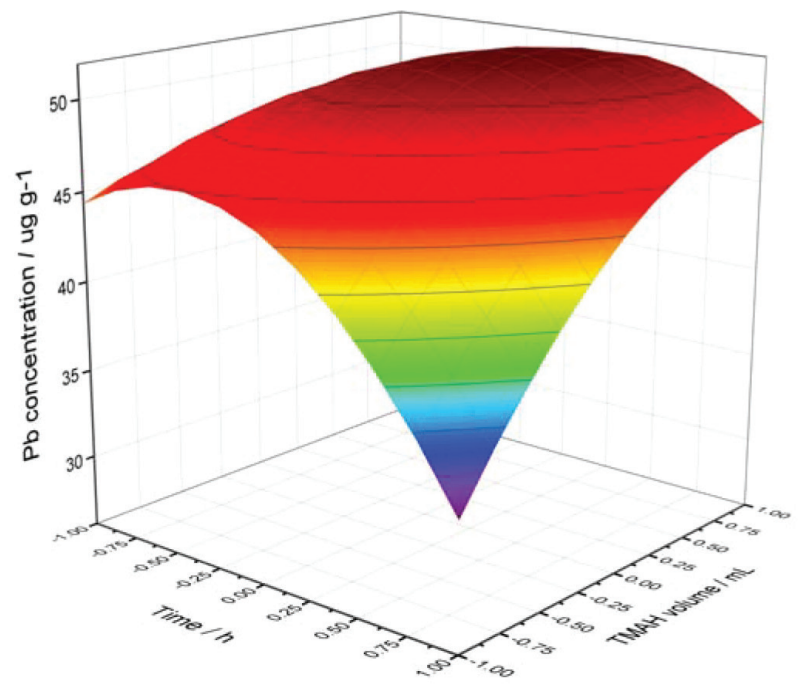

Figure 3. Response surface for $\mathrm{Pb}$ content as functions of TMAH volume $(\mathrm{mL})$ and time of solubilization $(\mathrm{h})$.
Figures of merit

For both sample preparation methods, accuracy was estimated by addition and recovery experiments as shown in Table 5. The obtained results were between $90 \pm 1$ and $105 \pm 1 \%$ for complete digestion and from $90 \pm 2$ to $95 \pm 3 \%$ for alkaline solubilization, which shows a good recovery ${ }^{35}$ for $\mathrm{Pb}$ determination for both methods. The precision of the methods was evaluated by the obtained RSD, which presented values below $10 \%$.

The other figures of merit were summarized in Table 6 . For both preparation methods, linearity was obtained for the same work range: 5.0 and $40 \mu \mathrm{g} \mathrm{L}-1 \mathrm{~Pb}$, using external calibration curves with standard solutions prepared separately in both media $\left(0.2 \%(\mathrm{v} / \mathrm{v}) \mathrm{HNO}_{3}\right.$ or $1.75 \%(\mathrm{v} / \mathrm{v})$ TMAH), according to the case. The limits of detection (LOD) and quantification (LOQ) obtained for the methods were 0.10 and $0.32 \mu \mathrm{g} \mathrm{g}^{-1}$ for complete digestion and 0.10 and $0.33 \mu \mathrm{g} \mathrm{g}^{-1}$ for alkaline solubilization, respectively. Comparing the two methods, no significant difference was observed for the limits of detection and quantification, indicating that the solubilization of chicken tissues with TMAH can be used without detection loss.

As shown in Table 6, the characteristic mass calculated for $\mathrm{Pb}$ in acid and alkaline media was 10 and $13 \mathrm{pg}$, respectively. The small difference between these values suggests a similar sensitivity for the determination of $\mathrm{Pb}$ in both studied conditions. Besides, these values are in good agreement with the values reported (characteristic mass between 14.2 and $45.8 \mathrm{pg}$ ) for $\mathrm{Pb}$ determination in biological samples, using coated graphite tubes and others chemical modifiers. ${ }^{36}$ However, it is important to emphasize that in the present study the conventional graphite tube was employed, to which the TMAH medium seems to be very suitable.

\section{Considerations for routine analysis}

In the present study, it has been demonstrated the potential of alkaline solubilization for the sample preparation of edible

Table 5. Recovery values obtained for $\mathrm{Pb}$ after complete digestion and alkaline solubilization for composite samples of chicken tissues

\begin{tabular}{|c|c|c|c|c|c|}
\hline \multirow{2}{*}{ Sample } & \multicolumn{2}{|c|}{$\mathrm{Pb}$ content $/\left(\mu \mathrm{g} \mathrm{g}^{-1}\right)$} & \multirow{2}{*}{$\begin{array}{l}\text { Added } \mathrm{Pb} \text { content / } \\
\left(\mu \mathrm{g} \mathrm{L}^{-1}\right)\end{array}$} & \multicolumn{2}{|c|}{ Recovery / \% } \\
\hline & Complete digestion & Alkaline solubilization & & Complete digestion & Alkaline solubilization \\
\hline \multirow{2}{*}{ Gizzard } & \multirow{2}{*}{$<0.32$} & \multirow{2}{*}{$<0.33$} & 5.0 & $93 \pm 1$ & $94 \pm 1$ \\
\hline & & & 30 & $105 \pm 1$ & $90 \pm 2$ \\
\hline \multirow{2}{*}{ Heart } & \multirow{2}{*}{$<0.32$} & \multirow{2}{*}{$<0.33$} & 5.0 & $90 \pm 1$ & $94 \pm 1$ \\
\hline & & & 30 & $91 \pm 1$ & $95 \pm 3$ \\
\hline \multirow{2}{*}{ Liver } & \multirow{2}{*}{$<0.32$} & \multirow{2}{*}{$<0.33$} & 5.0 & $98 \pm 1$ & $91 \pm 1$ \\
\hline & & & 30 & $100 \pm 1$ & $95 \pm 1$ \\
\hline
\end{tabular}


Table 6. Linearity, LOD, LOQ and characteristic mass obtained for $\mathrm{Pb}$ analysis using complete digestion and alkaline solubilization. Linear range: $5.0-40 \mu \mathrm{g} \mathrm{L} \mathrm{L}^{-1} \mathrm{~Pb}$

\begin{tabular}{|c|c|c|c|c|c|}
\hline Method & $\begin{array}{c}\text { Linear correlation } \\
\text { coefficient }\end{array}$ & Curve equation & $\begin{array}{l}\text { Instrumental } \mathrm{LOD}^{\mathrm{a}} \\
\text { and } \mathrm{LOQ}^{\mathrm{b}} /\left(\mu \mathrm{g} \mathrm{L}^{-1}\right)\end{array}$ & $\begin{array}{c}\text { Method } \mathrm{LOD}^{\mathrm{c}} \\
\text { and } \mathrm{LOQ}^{\mathrm{c}} /\left(\mu \mathrm{g} \mathrm{g}^{-1}\right)\end{array}$ & $\mathrm{m}_{0}{ }^{\mathrm{d}} / \mathrm{pg}$ \\
\hline Complete digestion & 0.9984 & $\mathrm{~A}=0.0136[\mathrm{~Pb}]+0.1077$ & 0.97 and 3.2 & 0.10 and 0.32 & 10 \\
\hline Alkaline solubilization & 0.9925 & $\mathrm{~A}=0.0181[\mathrm{~Pb}]-0.0783$ & 0.99 and 3.3 & 0.10 and 0.33 & 13 \\
\hline
\end{tabular}

${ }^{a} \mathrm{LOD}$ (limit of detection) was calculated as three times the standard deviation $(\mathrm{n}=10)$ for a blank solution $\left(\mathrm{HNO}_{3} 0.2 \% \mathrm{v} / \mathrm{v}\right.$ and $\left.\mathrm{TMAH} 1.75 \% \mathrm{v} / \mathrm{v}\right)$; ${ }^{b} \mathrm{LOQ}$ (limit of quantification) was calculated as ten times the standard deviation $(\mathrm{n}=10)$ for the same blank solution used for the LOD estimative; ${ }^{\mathrm{c}}$ correction factor of sample was 0.1 (to obtain final results in $\mu \mathrm{g} \mathrm{g}^{-1}$ ); ${ }^{\mathrm{d}} \mathrm{m}_{0}$ : characteristic mass.

parts of chicken over traditional acid digestion. The method employing TMAH was optimized with satisfactory efficiency and accuracy and it is suitable for routine analysis, since it would be possible to prepare samples in sequential batches, with low manipulation (single bottle) and, consequently, low contamination. Besides, the use of a single bottle allows the analyst to employ different sample dilutions to improve the detection of the method, if necessary. Besides that, the sample preparation is carried out at room temperature, without application of energy for heating.

On the other hand, in order to evaluate the performance of conventional and pyrolytic graphite furnaces to $\mathrm{Pb}$ quantification in edible parts of chicken, some figures of merit were obtained and presented in Table 7.

As shown in Table 7, the conventional graphite tube presented higher sensitivity and lower LOD and LOQ for both studied media (and most importantly for the alkaline medium) than the pyrolytic graphite furnace. The results demonstrate that conventional graphite furnace, normally less expensive than pyrolytic ones, can be used for $\mathrm{Pb}$ determinations in these edible samples until 900 burning cycles with no detection level reduction, under the presented studied conditions. All the above results show that the method could be applied not only by academic researchers but also in routine analysis due to the reduced costs of each analysis.

\section{Raman spectroscopy data}

Figure 4 shows the FT-Raman spectra obtained for raw dried chicken cuts before alkaline treatment. It may be noticed that samples from different tissues have differences in the spectral profile, justified by differences in their chemical composition.

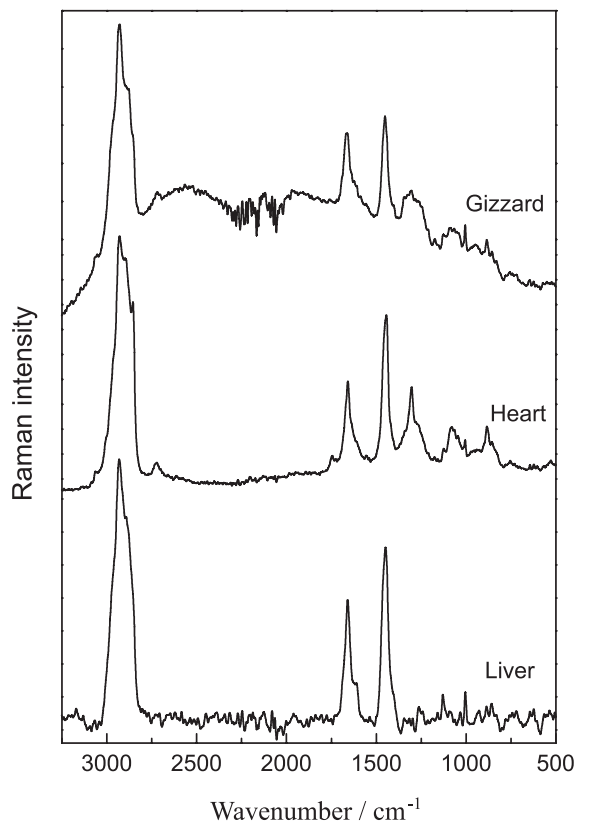

Figure 4. FT-Raman spectra of chicken tissues before alkaline solubilization.

Table 8 shows the main vibrational bands observed at chicken tissues Raman spectra before and after alkaline solubilization and their tentative assignments to vibrational modes and tissue component, based on comparisons with previously published data. Figure 5 shows the Raman spectra of chicken tissues before the

Table 7. Performance evaluation of conventional and pyrolytic furnaces for $\mathrm{Pb}$ determination in chicken meat. Linear range: $5.0-40 \mu \mathrm{g} \mathrm{L}^{-1} \mathrm{~Pb}$

\begin{tabular}{lccccc}
\hline Method & Graphite furnace & Curve equation & $\begin{array}{c}\text { Instrumental LOD } \\
\text { and LOQ } /\left(\mu \mathrm{L} \mathrm{L}^{-1}\right)\end{array}$ & $\begin{array}{c}\mathrm{Method} \mathrm{LOD}^{\mathrm{c}} \\
\mathrm{and} \mathrm{LOQ}^{\mathrm{c}} /\left(\mu \mathrm{g} \mathrm{g}^{-1}\right)\end{array}$ \\
\hline Complete digestion & $\mathrm{C}^{\mathrm{a}}$ & $\mathrm{A}=0.0136[\mathrm{~Pb}]+0.1077$ & 0.97 and 3.2 & 0.10 and 0.32 & 10 \\
& $\mathrm{P}^{\mathrm{b}}$ & $\mathrm{A}=0.0114[\mathrm{~Pb}]+0.1040$ & 1.0 and 3.4 & 0.10 and 0.34 & 12 \\
\hline \multirow{2}{*}{ Alkaline solubilization } & $\mathrm{C}$ & $\mathrm{A}=0.0181[\mathrm{~Pb}]+0.0783$ & 0.99 and 3.3 & 0.10 and 0.33 & 13 \\
& $\mathrm{P}$ & $\mathrm{A}=0.0054[\mathrm{~Pb}]+0.0440$ & 2.0 and 6.9 & 0.21 and 0.69 \\
\hline
\end{tabular}

${ }^{\mathrm{a}} \mathrm{C}$ : conventional graphite tube; ${ }^{\mathrm{P}} \mathrm{P}$ : pyrolytic graphite tube; ${ }^{\mathrm{c}}$ correction factor of sample was 0.1 (to obtain final results in $\mu \mathrm{g} \mathrm{g}^{-1}$ ); ${ }^{\mathrm{d}} \mathrm{m}_{0}$ : characteristic mass. 
Table 8. Tentative assignment ${ }^{37,38}$ of the Raman spectrum of chicken tissues before and after alkaline solubilization (residues)

\begin{tabular}{lcc}
\hline Wavenumber $/ \mathrm{cm}^{-1}$ & Tentative assignment & Component \\
\hline $3035-3052$ & $v_{\text {sym }}(=\mathrm{C}-\mathrm{H})$ & protein \\
$2929-2935$ & $v_{\text {as }}\left(\mathrm{CH}_{2}\right) / \mathrm{v}_{\text {sym }}\left(\mathrm{CH}_{3}\right)$ & lipids \\
$2879-2899$ & $v_{\text {sym }}\left(\mathrm{CH}_{3}\right)$ & lipids \\
$2850-2854$ & $v_{\text {sym }}\left(\mathrm{CH}_{2}\right)$ & lipids \\
$2715-2733$ & $v(\mathrm{C}-\mathrm{H})$ & lipids \\
1600 & ring $v(\mathrm{C}-\mathrm{C})$ & amino acids residues \\
& & (Phe, Trp, Tyr $)$ \\
$1658-1672$ & amide I & protein \\
$1444-1458$ & $\delta(\mathrm{CH})$ & lipids \\
$1260-1346$ & amide III & protein \\
$1124-1130$ & Arg & protein residues \\
$1063-1076$ & Trp & protein residues \\
$954-1005$ & Phe $(v-r i n g)$ & protein residues \\
$883-892$ & Trp (v-ring) & protein residues \\
$856-858$ & Tyr (v-ring) & protein residues \\
$754-758$ & Trp (v-ring) & protein residues \\
\hline
\end{tabular}

Phe: phenylalanine; Trp: tryptophan; Tyr: tyrosine; Arg: arginine; $v$ : stretching; $v_{\mathrm{as}}$ : anti-symmetric stretching; $\mathrm{v}_{\mathrm{sym}}$ : symmetric stretching; $\delta$ : scissoring mode.

solubilization and the residues obtained after alkaline treatment.

Comparing the Raman spectra of chicken tissues samples before and after alkaline treatment in Figure 5, it can be noticed that TMAH seems to act on solubilization following a similar mechanism for all viscera investigated in this study, with small differences. In general, the spectra profile of the three different samples is similar comparing the existent bands (before or after the solubilization procedure). Specifically, the main vibrational bands observed are related to lipids, proteins and amino acids (such as arginine, phenylalanine, tryptophan and tyrosine). ${ }^{37,38}$ On the other hand, it was obtained a significant decrease in the Raman intensity of these vibrational modes, when comparing spectra profile after the treatment (less intense) with the one obtained before.

Regarding the small differences found in the TMAH action, the bands in the range $3035-3052 \mathrm{~cm}^{-1}$, assigned to symmetric stretch of $(=\mathrm{CH})$ groups, related to vibrational modes of proteins, cannot be observed in Raman spectra of the liver sample residue. ${ }^{37}$ This indicated that alkaline treatment was more effective for proteins for the liver sample solubilization when compared with other chicken tissues.

For the heart sample residue, the bands at 1130 and $1005 \mathrm{~cm}^{-1}$, assigned to arginine and phenylalanine vibrational modes, cannot be observed after solubilization process. The same behavior was observed for the vibrational band at $756 \mathrm{~cm}^{-1}$ attributed to stretching of tyrosine ring for the gizzard sample residue. ${ }^{38}$

The aforementioned studies have shown that TMAH acts mainly in solubilization of proteins, as was expected based on the literature. ${ }^{9}$ However, the changes observed in the Raman profile spectra with the alkaline treatment of the tissue samples compared to raw ones, indicated that this reagent can also act over other kinds of organic compounds, such as lipids. These results indicate that this type of sample preparation could be applied for the determination of metals bound preferentially to these compounds, in addition to proteins. In other words, the Raman spectroscopy data analysis explains why TMAH is so efficient for sample preparation prior to metals analysis in different matrices.
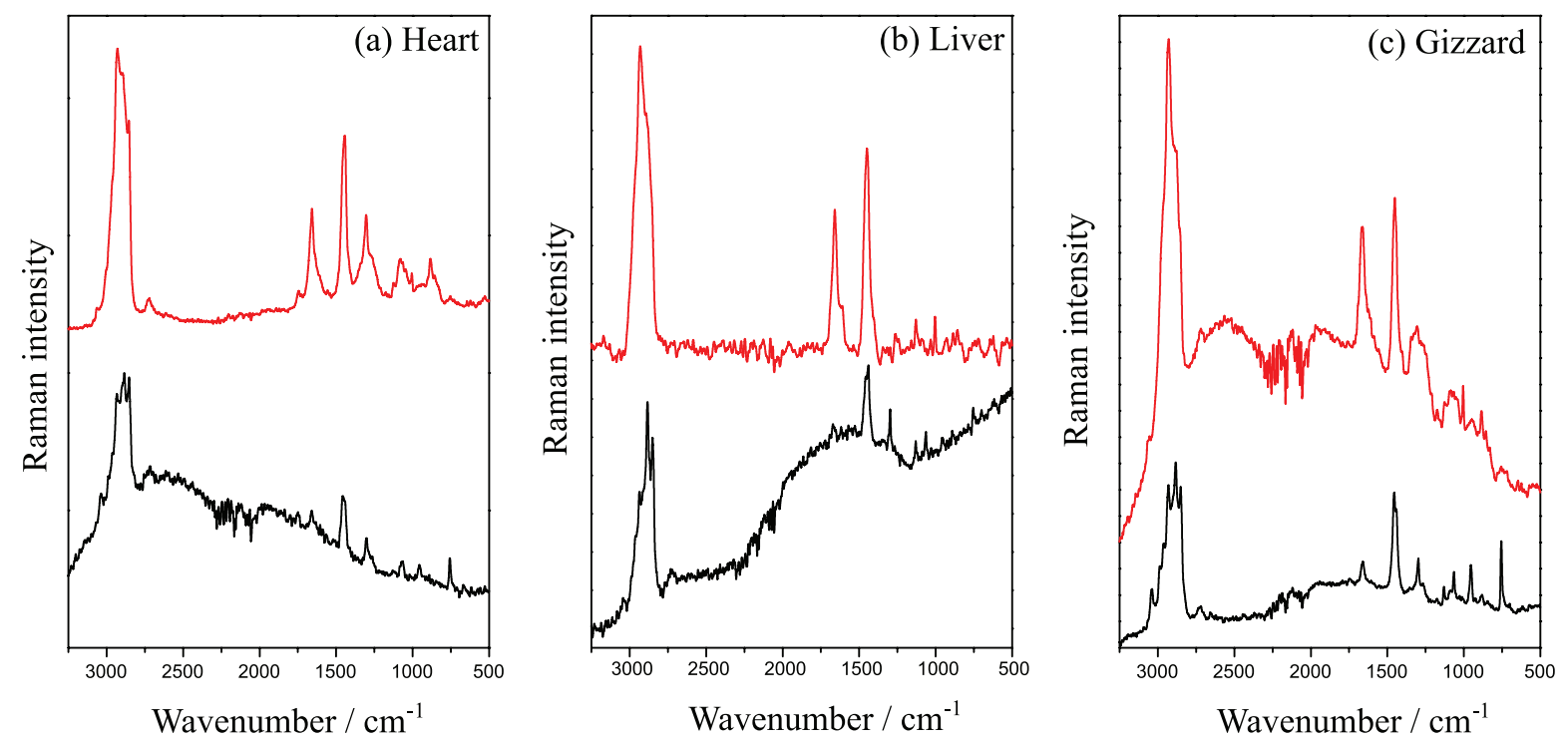

Figure 5. FT-Raman spectra of chicken tissues: (black, lower curve) before solubilization; (red, upper curve) residues obtained after alkaline solubilization. 


\section{SEM-EDS results}

Although the residues masses of chicken tissues alkaline solubilization were below $1 \% \mathrm{~m} / \mathrm{m}$ of the total sample mass, indicating the solubilization was almost complete, it was necessary to understand not only its composition but also to verify if any analyte $(\mathrm{Pb})$ would be present within the residue after the sample treatment.

In this sense, the scanning electron microscopy coupled to SEM-EDS was used to elucidate the inorganic composition of these residues. This approach is usually performed in studies related to morphology and elemental analysis of surface materials ${ }^{39}$ and was employed in this study due to the facility of carrying out elemental analysis of small sample amounts without sample preparation.

Qualitatively, the following elements were detected with good reliability: $\mathrm{C}, \mathrm{Mg}, \mathrm{Al}, \mathrm{P}$ and $\mathrm{Ca}$. Thus, comparing these results with Raman spectroscopy data, it can be concluded that the $\mathrm{C}$ in the residues correspond to organic compounds, mainly lipids, since most of the vibrational modes observed in Raman spectra were attributed to these compounds. In other hand, the remaining detected elements may be in the form of mineral salts or hydroxides due to the high sample $\mathrm{pH}$ provided by TMAH. Besides, no micro constituents such as $\mathrm{Fe}, \mathrm{Cu}$ and $\mathrm{Zn}$ and neither other trace contaminants were detected. These results show that the developed method of sample preparation using TMAH is appropriate to determine not only $\mathrm{Pb}$ but can be applied to elements not detected in the residues ( $\mathrm{Fe}, \mathrm{Cu}$ and $\mathrm{Zn}$ ).

\section{Conclusions}

In this work, an analytical procedure for sample preparation using an alkaline reagent and the concept of the use of single bottle was investigated for the analysis of edible chicken tissues by GFAAS. The analyte investigated was $\mathrm{Pb}$, but other contaminants could be, probably, determined employing the same sample preparation. The method allowed the solubilization of different chicken tissues and the analysis presented good accuracy and precision.

The method was applied to 15 unknown samples and the obtained results indicated that there is no detectable $\mathrm{Pb}$ in the chicken tissues evaluated in this work. The above result is diverse from the ones reported in studies abroad Brazil, but very good from the point of view of food security. Besides, the method developed proposes the use of conventional graphite tubes with an analytical performance comparable to the pyrolytic ones. This information brings an additional advantage for routine analysis since it can diminish the analysis costs.
It was demonstrated the potential of Raman spectroscopy as a monitoring tool for alternative sample preparations. The technique presented adequate sensitivity to differentiate the chicken tissues before and after treatment. The Raman spectroscopy results showed that TMAH acts on proteins but also on other organic compounds, bringing new data on the solubilization mechanisms by this reagent.

Finally, the small mass of sample residue $(<1 \% \mathrm{~m} / \mathrm{m})$ that remains in suspension, after sample solution homogenization, has both organic and inorganic compounds and its composition may not interfere in the analytical results.

\section{Supplementary Information}

Supplementary data are available free of charge at http://jbcs.sbq.org.br as PDF file.

\section{Acknowledgments}

The authors gratefully acknowledge Fundação de Amparo à Pesquisa do Estado de Minas Gerais (FAPEMIG), INCTBio (FAPESP grant No. 2014/50867-3 and CNPq grant No. 465389/2014-7) and Coordenação de Aperfeiçoamento de Pessoal de Nível Superior (CAPES) for financial support. We also thank Dr Denise Lowinshon and Dr Gustavo Andrade for their carefully language revision and Dr Luiz Fernando Cappa de Oliveira from Núcleo de Espectroscopia e Estrutura Molecular (NEEM) for SEM-EDS measurements.

\section{References}

1. World Health Organization, Summary of Toxicological Data of Certain Food Additives and Contaminants, WHO, Roma, 1978. Available at http://www.inchem.org/documents/jecfa/jecmono/ v13je13.htm, accessed in August 2017.

2. Schifer, T. S.; Junior, S. B.; Montano, M. A. E.; Infarma 2005, 17,5 .

3. BRASIL, Resolução RDC No. 42, de 29 de agosto de 2013, Dispõe sobre o Regulamento Técnico MERCOSUL sobre Limites Máximos de Contaminantes Inorgânicos em Alimentos, Diário Oficial da União: Brasília, DF, 30 de agosto, 2013. Available at http://portal.anvisa.gov.br/documents/33916/393845/ RDC\%2Bn\%C2\%BA\%2B42_2013final.pdf/eec629cf-8d17422b-a362-366b275c1a00?version=1.0, accessed in August 2017.

4. Commission Regulation (EC) No. 1881/2006 of 19 December 2006, Setting Maximum Levels for Certain Contaminants in Foodstuffs, Official Journal of the European Union, 2006. Available at http://eur-lex.europa.eu/legal-content/EN/TXT/PDF/?uri= CELEX:32006R1881\&from=EN, accessed in August 2017. 
5. Mercosur Technical Regulation, GMC No. 12/2011, Reglamento Técnico Mercosur sobre Límites Máximos de Contaminantes Inorgánicos en Alimentos (Derogación de las Res. GMC No. 102/94 y No. 35/96), Grupo Mercado Común: Asunción, Paraguay, 2011. Available at http://www.mercosur. int/innovaportal/v/3186/2/innova.front/resoluciones-2011, accessed in August 2017.

6. Krug, F. J.; Métodos de Preparo de Amostras, Fundamentos sobre Preparo de Amostras Orgânicas e Inorgânicas para Análise Elementar, $1^{\text {a }}$ ed.; Piracicaba: Piracicaba, Brazil, 2008.

7. Lopez-Garcia, I.; Briceno, M.; Hernandez-Cordoba, M.; Anal. Chim. Acta 2011, 699, 11.

8. Krishna, M. V. B.; Karunasagar, D.; Anal. Methods 2015, 7, 1997.

9. Nobrega, J.A.; Santos, M. C.; de Sousa, R. A.; Cadore, S.; Barnes, R. M.; Tatro, M.; Spectrochim. Acta, Part B 2006, 61, 465.

10. Ribeiro, A. S.; Curtius, A. J.; Pozebon, D.; Microchem. J. 2000, 64, 105.

11. Batista, B. L.; Rodrigues, J. L.; Nunes, J. A.; Tormen, L.; Curtius, A. J.; Barbosa Jr., F.; Talanta 2008, 76, 575.

12. da Silva, J. B. B.; Borges, D. L. G.; Andreia, M.; da Veiga, M. S.; Curtius, A. J.; Welz, B.; Talanta 2003, 60, 977.

13. Martins, P.; Pozebon, D.; Dressler, V. L.; Kemieciki, G. A.; Anal. Chim. Acta 2002, 470, 195.

14. Pereira, L. D. A.; Windmöller, C. C.; Silva, J. B. B.; Borges Neto, W.; Quim. Nova 2011, 34, 1167.

15. Giacomelli, M. B. O.; Lima, M. C.; Stupp, V.; de Carvalho, R. M.; da Silva, J. B. B.; Barrera, P. B.; Spectrochim. Acta, Part B 2002, 57, 2151.

16. de Sousa, R. A.; Sabarense, C. M.; Prado, G. L. P.; Metze, K.; Cadore, S.; Talanta 2013, 104, 90.

17. Noremberg, S.; Veiga, M.; Bohrer, D.; Viana, C.; do Nascimento, P. C.; de Carvalho, L. M.; Mattiazzi, P.; Anal. Methods 2015, 7, 500 .

18. Torres, D. P.; Martins-Teixeira, M. B.; Cadore, S.; Queiroz, H. M.; Anal. Methods 2016, 8, 4263.

19. de Almeida, M. R.; Oliveira, K. S.; Stephani, R.; de Oliveira, L. F. C.; Anal. Lett. 2012, 45, 2589.

20. Reid, L. M.; O’Donnell, C. P.; Downey, G.; Trends Food Sci. Technol. 2006, 17, 344.
21. Lopez-Diez, E. C.; Bianchi, G.; Goodacre, R.; J. Agric. Food Chem. 2003, 51, 6145.

22. Goodacre, R.; Radovic, B. S.; Anklam, E.; Appl. Spectrosc. 2002, 56, 521.

23. Thompson, M.; Ellison, S. L. R.; Fajgelj, A.; Willetts, P.; Wood, R.; Pure Appl. Chem. 1999, 71, 337.

24. IUPAC, Compendium of Chemical Terminology, Gold Book, version 2.3.3; IUPAC: Prague, 2014.

25. Welz, B.; Sperlin, M.; Atomic Absorption Spectrometry, $3^{\text {rd }}$ ed.; Wiley-VCH: New York, USA, 1999.

26. Chiba, M.; Shinohara, A.; Fresenius'J. Anal. Chem. 1999, 363, 749.

27. Berghof, Application Report, Microwave Pressure Digestion SpeedWave Four ${ }^{\circledR}$, Food, Pharma, Cosmetics, V 8.0, Berghof Products + Instruments GmbH: Eningen, Germany, 2013.

28. Lima, E. C.; Barbosa, F.; Krug, F. J.; Tavares, A.; Talanta 2002 , 57, 177.

29. Carrilho, E.; Gonzalez, M. H.; Nogueira, A. R. A.; Cruz, G. M.; J. Agric. Food Chem. 2002, 50, 4164.

30. Gonzalez, M. H.; Souza, G. B.; Oliveira, R. V.; Forato, L. A.; Nóbrega, J. A.; Nogueira, A. R. A.; Talanta 2009, 79, 396.

31. Nóbrega, J. A.; Pirola, C.; Fialho, L. L.; Rota, G.; de Campos Jordão, C. E. K. M. A.; Pollo, F.; Talanta 2012, 98, 272.

32. Souza, S. N. P.; Nascentes, C. C.; Costa, L. M.; Anal. Methods 2013, 5, 6411.

33. Rodrigues, M. I.; Iemma, A. F.; Planejamento de Experimentos e Otimização de Processos, $1^{\text {a }}$ ed.; Editora Casa do Pão: Campinas, Brazil, 2009.

34. Bezerra, M. A.; Santelli, R. E.; Oliveira, E. P.; Villar, L. S.; Escaleira, L. A.; Talanta 2008, 76, 965.

35. Wood, R.; Trends Anal. Chem. 1999, 18, 624.

36. Acar, O.; Talanta 2001, 55, 613.

37. Campos, N. S.; Oliveira, K. S.; de Almeida, M. R.; Stephani, R.; de Oliveira, L. F. C.; Molecules 2014, 19, 18980.

38. Movasaghi, Z.; Rehman, S.; Rehman, I. U.; Appl. Spectrosc. Rev. 2007, 42, 493.

39. Figueroa, M. P.; Contreras, J. S.; Micron 2007, 38, 668.

Submitted: May 3, 2017

Published online: August 16, 2017 